\title{
The Effects of a havruta Method on the Self-directed Learning and Learning Motivation
}

\author{
EunJung Chung ${ }^{1}$, Byoung-Hee Lee ${ }^{2}$ \\ 'Department of Physical Therapy, Andong Science College, Republic of Korea \\ ${ }^{2}$ Department of Physical Therapy, Sahmyook University, Republic of Korea
}

Purpose: This study aims to verify the effects of a havruta class on the self-directed learning and motivation for learning of college physical therapy students.

Methods: A descriptive study of the use of the havruta approach to learning and teaching. The subjects were 95 students of College A who had registered for musculoskeletal examination, assessment and practice in the second semester of 2018. The havruta method was applied for students for one semester, after which a paired t-test was performed to compare the dependent variables (self-directed learning and learning motivation).

Results: There were significant differences in self-directed learning (learning plan, execution and evaluation) and learning motivation (attention, relevance, confidence, and satisfaction).

Conclusion: These results suggest that the havruta approach to learning improves self-directed and motivation for learning. A follow-up study is necessary to further investigate the application of havruta in relation to evidence of sound inquiry processes within approaches to learning.

Keywords: Havruta; Self-directed learning; Learning motivation

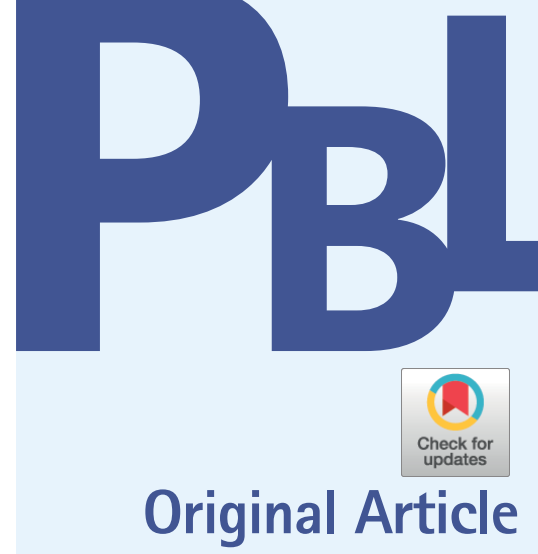

pISSN 2288-8675 • elSSN 2508-9145

J Probl Based Learn 2019;6(1):3-9

https://doi.org/10.24313/jpbl.2019.00143

Received: February 28, 2019

Revised: March 24, 2019

Accepted: April 27, 2019

Corresponding author:

EunJung Chung

Andong Science College 189

Seosun-gil, Seohu-myeon, Andong, 760-709, Republic of Korea

Tel: +82-54-851-3752

Fax: +82-54-852-9907

E-mail: eunjung1984@hotmail. co.kr

\section{INTRODUCTION}

The world has entered the age of biotechnology and artificial intelligence, and encouraging students to test the value of information and knowledge ie to become information fluent, is becoming more important. The education system is also changing in order to adapt to the times. As a part of this, the cultivation of creative talent is a core goal of many nation states, and Israel's Jewish education methods are attracting attention; havruta (or chavrusa) is one such method (Oh, 2014).

Havruta (or chavrusa) is a traditional Jewish way of learning that involves understanding and solving problems through dialogue between people using interaction processes, sometimes in pairs talking, discussing, and debating with each other (Kent \& Allison, 2012). Havluta, studying with a critical friend, is justified as Talmud said because often, "There is more to learn from a friend than to learn from a teacher..." (Jeon, 2015).

The American Behavioral Science Research Institute (2013) studied the rate of memory formation in the brain 24 hours after studying in various ways. The results were as follows: Lecture explanations: $5 \%$; reading: $10 \%$; audiovisual: $20 \%$; demonstration: $30 \%$. On the other hand better results arose from discussions: 50\%; direct practice: $75 \%$; and teaching: $90 \%$ (Havruta Class Research Society, 2013). In order to get the same effects, taking personal responsibility by studying for one hour using a critical friend method (as with havruta), is claimed to be more efficient than traditional lecture-based teaching (Jeon, 2016).

Havruta begins after the teacher selects a text; the learning activity includes three phases:

(C) Copyright 2019 International Society for Problem-Based Learning

(c) This is an Open Access article distributed under the terms of the Creative Commons Attribution Non-Commercial License (http://creativecommons.org/licenses/ by-nc/4.0/) which permits unrestricted non-commercial use, distribution, and reproduction in any medium, provided the original work is properly cited. 
first, one partner reads aloud while the other listens carefully; often the text is reread multiple times in accordance with reading norms. Second, the participants take turns articulating the explicit and implicit meanings of the text. Third, one challenges their partner to think more deeply (Shargel \& Laster, 2016).

The merit of a havruta class is that by asking questions and having discussions, one can stimulate the brain; havruta learning requires different ways of thinking and exploring the thoughts of others, so it leads to more varied and creative thoughts. Havruta is a form of self-directed learning (SDL) because students must take responsibility to learn, find additional materials, and engage in independent thinking in order to prepare for the discussion. In addition, because havruta involves discussion, it develops students' abilities to communicate, listen and persuade others of therir views (Jeon, 2016).

The previous domestic studies on havruta classes focused on students in elementary school classes in various subjects, such as mathematics (Kang, 2017; Shim, 2017;Jeon, 2016), science (Kwak, 2017;Jang, 2015), and English (Kang, 2017). There have not been many studies on middle school (Kim, 2018;Lee, 2017), or high school students (Kang \& Cho, 2017; Shin, 2016;Yun, 2016). Research on the application of havruta to learning activities in college classes has been limited in Korea, with the exception of studies on online discussions (Joung \& Choi, 2015) and psychology classes (Go, Min, \& Song, 2017). This study aims to verify the effects of a havruta class on SDL and learning motivation of college physical therapy students.

\section{METHODOLOGY}

\section{Design, setting and participants}

The researchers utilized a descriptive pretest-posttest study design with a single group of students $(\mathrm{n}=95)$ from College A in Gyeongbuk province undertaking one subject within a physical therapy program. The dependent variables for this study were self-directed learning and learning motivation for students involved with the first-grade topic, musculoskeletal examination and assessment, and practice. The subject entails learning the basics of measuring the joint's range of motion and muscle testing in physical therapy.

The havruta method was applied to students for one semester; actual classes involved 21 hours-3 hours per week for 7 out of 15 weeks. A paired t-test was performed to compare the dependent variables before and after the class. This study was approved by the Sahmyook University's institutional review board (IRB 2-7001793-AB-N-012018126HR). All subjects signed a written informed consent form prior to participation.

\section{Instructional design}

Havluta is all about encouraging student interactions: Talking, asking, and discussing issues in class. Jeon (2015) divided the technique into five different options:

\section{Question-centered}

Table 1 provides an overview of the sequence of activity. The teacher must adjust the number of questions according to the student's academic level.

\section{Argument-centered}

Table 2 provides details where a controversial topic is put up for discussion.

\section{Comparison-centered}

Table 3 describes the method of investigation where a topic is chosen for comparison and questions are prepared in class; the approach stimulates debate and deeper thought.

\section{Teaching friends}

Collaborative learning with a friend involves two students at an equivalent level, expressing their appreciation of knowledge and

Table 1. Question-centered havruta

\begin{tabular}{ll}
\hline Procedure & \multicolumn{1}{c}{ Description } \\
\hline $\begin{array}{l}\text { Asking a question } \\
\text { Pair discussion }\end{array}$ & $\begin{array}{l}\text { Reading a textbook and then asking a question } \\
\text { Sorting questions by type; discussion between } \\
\text { two people } \\
\text { Picking the best question }\end{array}$ \\
Group discussion & $\begin{array}{l}\text { Discussion by group about the best questions } \\
\text { Picking the best question and discussing/ } \\
\text { organizing contents of the discussion }\end{array}$ \\
Presentation & $\begin{array}{l}\text { Presentation by each group } \\
\text { Whole class discussion }\end{array}$ \\
\hline
\end{tabular}

Table 2. Argument-centered havruta

Procedure
$\begin{aligned} & \text { Researching the topics } \\ & \text { Pair controversy }\end{aligned} \quad \begin{gathered}\text { Setting a topic/ deciding for and against/ } \\ \text { investigating one's position } \\ \text { Controversy is generated by pairing two people } \\ \text { with different positions } \\ \text { Determining your partner's position through } \\ \text { debate with your partner }\end{gathered}$
Group controversy $\quad \begin{gathered}\text { Explaining each position and discussing as a } \\ \text { group } \\ \text { Organizing one's position and the grounds for } \\ \text { one's position }\end{gathered}$
Presentation
Phole class discussionting the group's position and grounds
Teacher holds discussion with students


Table 3. Comparison-centered havruta

\begin{tabular}{|c|c|}
\hline Procedure & Description \\
\hline Setting up & Setting up comparison subjects \\
\hline \multicolumn{2}{|c|}{$\begin{array}{l}\text { Investigating and posing Thorough } \\
\text { questions }\end{array}$} \\
\hline & Asking questions \\
\hline \multirow[t]{2}{*}{ Pair discussion } & $\begin{array}{l}\text { Ordering questions by dividing them into } \\
\text { progress and meta }\end{array}$ \\
\hline & $\begin{array}{l}\text { Discussing one-on-one/ picking one to three } \\
\text { good questions }\end{array}$ \\
\hline \multirow[t]{2}{*}{ Group discussion } & $\begin{array}{l}\text { Discussing the selected question in a group of } \\
\text { four to six people }\end{array}$ \\
\hline & $\begin{array}{l}\text { Picking the best question and having an } \\
\text { intense discussion }\end{array}$ \\
\hline Presentation & $\begin{array}{l}\text { Presenting good questions and discussion } \\
\text { around content }\end{array}$ \\
\hline Whole class discussion & Teacher holds a discussion with students \\
\hline
\end{tabular}

Table 4. Teaching friends

\begin{tabular}{|c|c|}
\hline Procedure & Description \\
\hline \multirow[t]{2}{*}{ Studying content } & Divide the range of textbooks into two \\
\hline & Study each part thoroughly \\
\hline Teaching a friend & One friend teaches the other first \\
\hline \multicolumn{2}{|c|}{$\begin{array}{l}\text { Asking questions while } A \text { friend asks keen questions while learning } \\
\text { learning }\end{array}$} \\
\hline \multirow[t]{2}{*}{ Changing positions } & Changing your position and teaching others \\
\hline & Keenly asking questions while learning \\
\hline $\begin{array}{l}\text { Questions that I do } \\
\text { understand }\end{array}$ & $\begin{array}{l}\text { Discussion with each other and organizing } \\
\text { questions that are not understood }\end{array}$ \\
\hline Whole class discussion & Teacher holds a discussion with students \\
\hline
\end{tabular}

Table 5. Posing a question

\begin{tabular}{|c|c|}
\hline Procedure & Description \\
\hline \multirow[t]{2}{*}{ Posing a question } & Thorough study of the range of textbooks \\
\hline & $\begin{array}{l}\text { Forming questions such as multiple choice and } \\
\text { short-answer questions }\end{array}$ \\
\hline \multirow[t]{2}{*}{$\begin{array}{l}\text { Refining question with a } \\
\text { partner }\end{array}$} & Discussing and refining the question in pairs \\
\hline & Choosing a good question with your partner \\
\hline \multirow[t]{2}{*}{$\begin{array}{l}\text { Refining question with a } \\
\text { group }\end{array}$} & $\begin{array}{l}\text { Refining question through group discussion } \\
\text { and choosing a good question }\end{array}$ \\
\hline & $\begin{array}{l}\text { Organizing intentions to present selected } \\
\text { questions }\end{array}$ \\
\hline Question presentation & Presenting question and intentions \\
\hline Whole class discussion & Teacher holds discussion with students \\
\hline
\end{tabular}

concepts and learning from each other; one student hears the explanation but can ask questions while continuing to listen. The details are shown in Table 4.

\section{Asking questions}

Asking questions involves formulating a question about material from a prescribed text, then refining the question through discussion in pairs, further refining the discussion in groups, and then having the teacher discuss the question with the whole class. The details are shown in Table 5.

The chosen instructional design and learning activities appropriate to the study's subject objectives were 'question-centered', 'comparison-centered', and 'teaching friend' options. This study applied "understanding of the record of evaluation" through comparison-centered havruta in the first session, and applied "explanation of subjective information, objective information, assessment, plan (SOAP note)" through question-centered. Table 6 provides the details.

\section{Instruments}

\section{Self-directed learning}

The self-directed learning (SDL) scale for college students proposed by Lee et al. (2003) was used. It consisted of 45 items including 3 ability factors and 8 sub-factors. A score of 1 indicated that SDL was lower, and a score of 5 meant it was higher.

The subscale items of SDL used in this study are shown in Table 7. The reliability of this study, determined using Cronbach's alpha, was $\alpha=.887$.

\section{Learning motivation}

A modified form of the learning motivation test tool developed by Keller (1987) was used. The questionnaire consisted of 34 items where levels of agreement ranged from "strongly disagree" (1) to "strongly agree" (5). The minimum score was 34 , maximum 170, with the average score 102. The minimum, maximum, and average scores for each subscale could be different because of the different number of subcategories. The subscale items are shown in Table 8 . The reliability of this study was determined to be $\alpha=.887$.

\section{Statistical analysis}

All statistical analyses were performed using SPSS version 21.0, and descriptive statistics were applied to demographics data. Internal consistency and reliability were determined using Cronbach's alpha, and a paired sample t-test was used for the assessment of the differences between the pre- and post-test sessions. The significance threshold was set to $\mathrm{p}<0.05$.

\section{RESULTS}

The comparative results on SDL after the havruta class are 
Table 6. Instructional design and activities

\begin{tabular}{|c|c|c|c|}
\hline \multicolumn{4}{|c|}{ Learning contents by week } \\
\hline Week & Topics & Contents & Activities (havruta method) \\
\hline 1 & Understanding assessment & -You can understand the record of evaluation & Comparison-centered \\
\hline 2 & & -You can explain the SOAP note & Question-centered \\
\hline \multicolumn{4}{|l|}{3} \\
\hline 4 & & -You can explain the ICF & Question-centered \\
\hline 5 & Measuring the range of joint motion & -You can understand the kinds of range of joint motion & Comparison-centered \\
\hline 6 & & - You can understand the testing method of the range of joint motion & Teaching friends \\
\hline 7 & & & \\
\hline
\end{tabular}

Table 7. Cronbach's alpha for SDL $(\mathrm{N}=95)$

\begin{tabular}{lllc}
\hline Subscale & \multicolumn{1}{c}{ Item contents } & \multicolumn{1}{c}{ Item number } & Total Cronbach's alpha \\
\hline Learning plan & Diagnosing learning needs & $1,2,3^{*}, 4^{*}, 5,6,7,8,9,10$ & .831 \\
& Goal setting & $11,12,13,14,15$ & $16,17,18,19,20$ \\
Learning execution & Identify resources for learning & Basic self-management ability & $21,22,23,24,25^{*}$ \\
& Choosing a learning strategy & $26,27,28,29,30$ \\
Learning evaluation & Continuity of learning execution & $31,32^{*}, 33,34^{*}, 35^{*}$ & .687 \\
& Effort attributed to results & $36,37^{*}, 38,39,40^{*}$ & .72 \\
& Self-reflection & $41,42,43,44,45$ & .887 \\
\hline
\end{tabular}

*Negative scoring item

Table 8. Cronbach's alpha for learning motivation $(\mathrm{N}=95)$

\begin{tabular}{lcc}
\hline Subscale & \multicolumn{1}{c}{ Item number } & Total Cronbach's alpha \\
\hline Attention & $1,4^{*}, 10,15,21,24,26^{*}, 29$ & 0.653 \\
Relevance & $3,6^{*}, 9,11^{*}, 17^{*}, 27,30,34$ & 0.611 \\
Confidence & $2,5,8^{*}, 13,20,22,23,25^{*}, 28$ & 0.715 \\
Satisfaction & $7^{*}, 12,14,16,18,19,31^{*}, 32,33$ & 0.721 \\
& Total & 0.887 \\
\hline
\end{tabular}

*Negative scoring item

shown in Table 9. The score for total SDL showed significant differences $(p=.000)$. The subscales of SDL showed significant differences (learning plan: $p=.000$, learning execution: $p=.001$, learning evaluation: $\mathrm{p}=.000$ ), but no significant differences were observed in goal setting $(\mathrm{p}=.056)$ and basic self-management ability $(\mathrm{p}=.118)$.

The comparative results on learning motivation after participation in the havruta class are shown in Table 10. Overall learning motivation showed significant differences $(p=.000)$ as did the elements of learning motivation: Attention, relevance, confidence, satisfaction all with significant differences $(p=.000)$.

\section{DISCUSSION}

Havruta, also spelled chavruta, is an Aramaic word meaning "friendship" or "companionship" (Liebersohn \& Aharon, 2006). In Orthodox Judaism, a havruta always refers to two students learning one on one. When three or more students learn together, they are also called a havruta. The Judaism Reform expanded the idea of a havruta to include two, three, four or even five individuals studying together (Moskowitz \& Rabbi, 2011).

Kent et al's (2012) study results showed that reading text and, discussing and interpreting it with others was a key to success; in many situations, it was possible for learners of many ages to complete complex exercises. The basic structure of the teaching method based on havruta was summarized as three elements: Stance, structure, and execution. Figure 1 shows the domains of havruta-inspired pedagogy and illustrates their overlapping nature. Structure refers to the design components the setup for learning. Teachers can explore the many design details of the structure that can support and facilitate learning. Havruta proponents emphasise the notion that attitudes and beliefs can profoundly affect the nature of the educational setting, especially relationships among the resources - the teachers, learners, and the text. The nature of the conversations that occur in the havruta 
Table 9. Comparison of self-directed learning before and after the havruta class (N=95)

\begin{tabular}{lllll}
\hline Variables & Pre-test & Post-test & Mean difference & $t(p)$ \\
\hline Self-directed learning & $2.72 \pm .35$ & $2.94 \pm .23$ & $-.22 \pm .43$ & $-4.953(.000)$ \\
Learning plan & $2.80 \pm .42$ & $3.04 \pm .31$ & $-.25 \pm .53$ & $-4.519(.000)$ \\
Diagnosing learning needs & $2.75 \pm .42$ & $2.98 \pm .24$ & $-.23 \pm .46$ & $-4.849(.000)$ \\
Goal setting & $2.90 \pm .67$ & $3.08 \pm .61$ & $-.18 \pm .90$ & $-1.934(.056)$ \\
Identify resources for learning & $2.77 \pm .61$ & $3.13 \pm .83$ & $-.35 \pm 1.07$ & $-3.194(.002)$ \\
Learning execution & $2.64 \pm .37$ & $2.82 \pm .33$ & $-.18 \pm .51$ & $-3.417(.001)$ \\
Basic self-management ability & $2.56 \pm .48$ & $2.71 \pm .73$ & $-.15 \pm .94$ & $-1.577(.118)$ \\
Choosing a learning strategy & $2.64 \pm .52$ & $2.84 \pm .47$ & $-.19 \pm .67$ & $-2.820(.006)$ \\
Continuity of learning execution & $2.72 \pm .43$ & $2.91 \pm .35$ & $-20 \pm .58$ & $-3.271(.002)$ \\
Learning evaluation & $2.70 \pm .45$ & $2.92 \pm .32$ & $-.21 \pm .53$ & $-3.938(.000)$ \\
Effort attributed to results & $2.74 \pm .47$ & $2.95 \pm .37$ & $-.21 \pm .62$ & $-3.318(.001)$ \\
Self-reflection & $2.67 \pm .65$ & $2.88 \pm .45$ & $-.22 \pm .73$ & $-2.917(.004)$
\end{tabular}

Table 10. Comparison of learning motivation before and after the havruta class $(\mathrm{N}=95)$

\begin{tabular}{lllll}
\hline Variables & Pre-test & Post-test & Mean difference & $t(p)$ \\
\hline Learning motivation & $2.55 \pm .36$ & $2.85 \pm .25$ & $-.29 \pm .41$ & $-6.908(.000)$ \\
Attention & $2.59 \pm .40$ & $2.91 \pm .36$ & $-.32 \pm .55$ & $-5.695(.000)$ \\
Relevance & $2.46 \pm .39$ & $2.78 \pm .29$ & $-.32 \pm .47$ & $-6.779(.000)$ \\
Confidence & $2.39 \pm .45$ & $2.66 \pm .31$ & $-.27 \pm .53$ & $-5.056(.000)$ \\
Satisfaction & $2.76 \pm .43$ & $3.02 \pm .33$ & $-.26 \pm .52$ & $-4.886(.000)$ \\
\hline
\end{tabular}

approach is critical. The six havruta practices - listening, articulating, wondering, focusing, supporting, and challenging - can help learners interpret texts together and can cultivate intellectual and relational skills in the process (Kent \& Cook, 2012).

In the twenty-first century, passively learning monolithic content in a uniform way is not appropriate; SDL ability as an outcome of learning is essential (Lee et al., 2003). SDL is a concept that illustrate that learners themselves are actively participating in learning and showing goal-oriented behavior. This is a process in which the learner himself/herself takes the initiative in learning, diagnoses his/her learning needs, sets learning goals, selects and executes appropriate learning strategies, and evaluates the selfachieved learning outcomes (Yang, 2000).

Yang (2018) investigated the effect of participation based havruta classes on SDL competence in learning events focused on morals. The results showed the percentage of respondents who valued learning and felt enthusiastic about it increased from $27 \%$ to $40 \%$. In addition, the percentage of students who responded that they were setting up a learning plan to engage with the learning objectives increased from $21 \%$ to $29 \%$. There were significant differences in SDL (involving developing a learning plan, execution, and evaluation). This finding suggests that the havruta technique helped students improve their ability to think

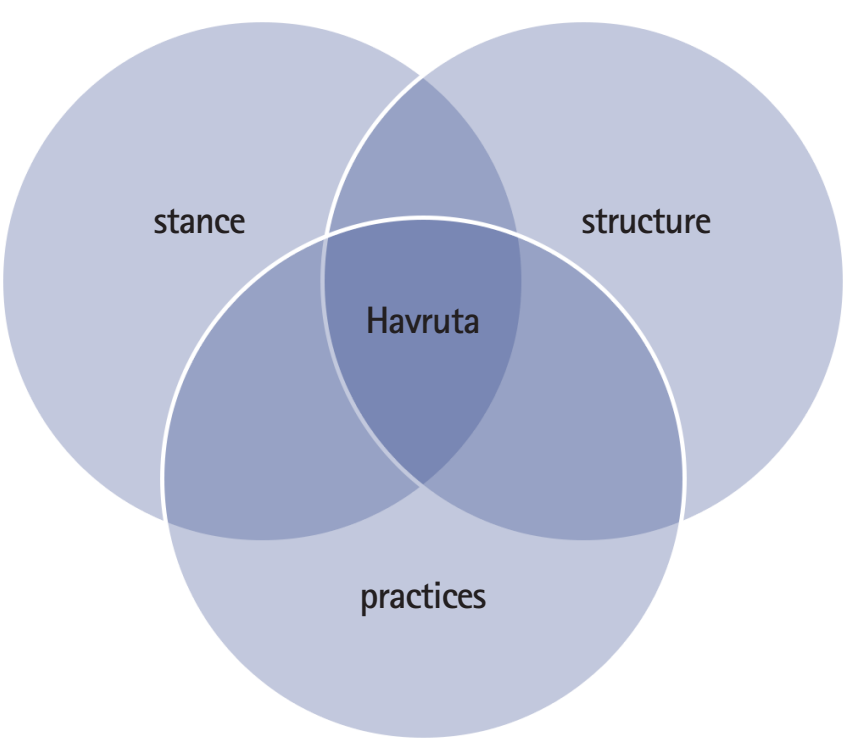

Figure 1. Havruta-inspired pedagogical framework

and learn through a process involving answering and asking questions, formulation of direct questions, and selection of good questions; this suggests that the learning processes contributed to increasing their self-direction in learning ability. 
Woolfolk (1988) reported that when learning activities are perceived as valuable to the learner, motivation is increased; one has a tendency to try to study hard. Brophy (1998) suggested that motivation reflects a tendency to perceive learning activities as meaningful and valuable and thus students are more likely to achieve the intended learning goals.

Kwak (2017) showed that havruta elementary science class participants demonstrated a statistically significant level of motivation toward learning (attention, relevance, confidence, and satisfaction) $(\mathrm{p}=.004)$. This finding suggests that a havruta class fosters interest in the process of questioning and responding to colleagues as an autonomous or self-directed learner.

\section{CONCLUSION}

This study examined the havruta approach, and analysis of pre and post-test results showed improvements in self-directed learning and learning motivation. Therefore, it is suggested that the approach has application to a broader range of subjects. The approach to learning and teaching encouraged more active learning; the students took more responsibility for their own learning. By focusing on allowing greater student autonomy, the teacher became more facilitative of the learning processes.

The study has several limitations. First, the subjects were physical therapy students, and there were not many subjects from which to generalize findings. Second, there was no control subject in this study. A follow-up study is needed to make a comparison between traditional teaching/learning activities and the more student-focussed and active havruta learning and teaching method. Third, the havruta class took the form of a conversation in which two people read a textbook and exchanged questions. Through communication between two people, they went through a process of speaking and explaining their thoughts. However, because the students were accustomed to the traditional lecture culture that does not leave much room for questions, the dialogue between the two people may have been awkward and unsustainable. Therefore, teaching and learning materials should be developed to provide more stimulating or engaging opportunities for collaborative and communicative activities. The paradigm shift towards greater access to and use of technology also suggests the need for studies on ways to conduct learning events in more blended modes of delivery, including studying online. The world of work today is heavily reliant on technological competence.

\section{ACKNOWLEDGEMENTS}

The authors acknowledge the contribution of Professor Margaret McMillan in the presentation of this paper.

\section{REFERENCES}

Brophy. (1998). Motivating students to learn. USA: Lawrence Erlbaum Assoc Inc.

Go, H., Min, H. D., \& Song, J. S. (2017). The effects of question-centered havruta lesson on the creative personality and problem-solving ability of preservice early childhood teachers. Journal of Learner-Centered Curriculum and Instruction, 17(13), 253-278.

Havruta Class Research Society. (2013). Havruta question teaching. Seoul: KyunghyangBP.

Jang, Y. S. (2015). The effect of the scientific process skills and academic achievement in science class Havruta discussion of the topic. Unpublished master's thesis, Busan National University, Busan, Korea.

Jeon, S. S. (2015). Class have any questions: elementary school, middle school. Seoul: KyunghyangBP.

Jeon, S. S. (2016). Nobel Prize 30\% the best way to study "Havruta". The Korea Society of Mathematical Education, 1, 46-50.

Jeon, H. G. (2016). An analysis of the effects of Havruta learning on student's attitude and achievement in mathematics. Unpublished master's thesis, Busan National University, Busan, Korea.

Joung, S., \& Cho, H. J. (2015). The effects of online discussion activities based on Israeli's havruta style on discussion ability and social problem-solving. The Korean Association for Educational Methodology Studies, 27(1), 39-66.

Kang, E. J. (2017). Design and application of an elementary mathematics lesson based on Havruta learning method. Unpublished master's thesis, Gyeongin National University, Gyeonggi-do, Korea.

Kang, E. J., \& Cho, C. K. (2017). The effects of Havruta class on high school student's geographical attitude and academic achievement. Journal of the Korean Association of Regional Geographers, 23(2), 420-436.

Kang, Y. K. (2017). Effects of the Havruta techniques using an internet English dictionary on the teaching of elementary English listening and speaking. Unpublished master's thesis, Seoul National University, Seoul, Korea.

Keller, J. M. (1987). Development and use of the ARCS model of instructional design. Journal of Instructional Development, 10(3), 2-10.

Kent, O., \& Allison, C. (2012). Three Partners in study: two peo- 
ple and a text. A Journal of Jewish Ideas, 42(6), 90-105.

Kent, O., \& Cook, A. (2012). Havruta inspired pedagogy: fostering an ecology of learning for closely studying texts with others. Journal of Jewish Education, 78, 227-253.

Kim, J. H. (2018). A study on teaching Janggu in middle school using the flipped learning and Havruta approaches. Unpublished master's thesis, Yonsei University, Seoul, Korea.

Kwak, E. (2017). The effects of the science class based on Havruta learning on the scientific learning motivation and scientific attitudes of elementary school student. Unpublished master's thesis, Busan National University, Busan, Korea.

Lee, S. K. (2017). A study on the music curriculum lesson of learning community based on the Havruta and flipped learning. Unpublished master's thesis, Kyungpook National University, Gyeongsangbuk-do, Korea.

Lee, S. J., Chang, Y. K., Lee, H. N., Park, K. Y. (2003). A study on the development of life-skills: communication, problem solving, and self-directed learning. Seoul: Korean Educational Development Institute.

Liebersohn, Aharon. (2006). World wide agora. USA: Lulu Press.

Rabbi, M.L.M. (2011). Turn it again-the joy of Shabbat tish. Scribe $24(5 \& 6)$.

Oh, D. (2014). Sociocultural background of Israel Jew's creativity.
The Journal of Education Research, 12(2), 103-131.

Shargel, R., \& Laster, B. P. (2016). Partner learning (Havruta) for close reading comprehension. English journal, 105(3), 63-68.

Shim, M. (2017). Analysis of communication characteristics of elementary mathematical gifted students in the Havruta learning method. Unpublished master's thesis, Gyeongin National University, Gyeonggi-do, Korea.

Shin, H. J. (2016). The effects of havruta education in mathematics teaching and learning: focused on the 10th grade student's function learning. Unpublished master's thesis, Chonnam National University, chonnam, Korea

Woolfolk. (1988). Educational psychology. N.J: Englewood Cliffs.

Yang, M. H. (2000). The study on development and validation of self-regulated learning model. Unpublished master's thesis, Seoul National University, Seoul, Korea.

Yang, S. S. (2018). The effect of participation based class on learning attitude and self-directed learning competency in moral subject classes: focusing action learning, visual thinking, havruta class. Unpublished master's thesis, Jeju National University, Jeju, Korea.

Yun, J. H. (2016). The effects of debate classes based on Havruta in mathematics education. Unpublished master's thesis, Busan National University, Busan, Korea. 